\title{
USE OF SESAME AND PROBIOTIC LACTOBACILLI IN MAKING NUTRACEUTICAL FERMENTED DAIRY PRODUCTS. \\ Aziz, Asmaa H.H. ${ }^{1}$ and Karima A. M. Aboeleinen ${ }^{2}$ ${ }^{1}$ Dairy Technology and ${ }^{2}$ Dairy Chemistry Departments, Animal Production Res. Inst., Dokki , Giza , Egypt
}

\begin{abstract}
Nutraceutical fermented milk product rich in polyunsaturated fatty acids and antioxidants was produced from buffaloes milk with $S$. thermophilus , Lb. gasseri or $L b$. rhamnosus and sesame seeds. Treatments were made as follows: $S$. thermophilus and Lb. gasseri ; S. thermophilus and Lb. rhamnousus ; $S$. thermophilus ; Lb. gasseri and $2 \%$ sesame ; S. thermophilus ; Lb. gasseri and $4 \%$ sesame seeds ; $S$. thermophilus ; Lb. rhamnousus and $2 \%$ sesame seeds and $S$. thermophilus ; $L$ b. rhamnousus and $4 \%$ sesame seeds.

Chemical, microbiological and organoleptic properties were determined in fresh product and throughout 15 days of storage at $6{ }^{\circ} \mathrm{C}$. The addition of sesame increased T.A, protein, fat, amino acids especially some essential amino acids and polyunsaturated fatty acids specially omega fatty acids. Streptococci and lactobbacili counts increased markedly by adding sesame. Mould and Yeast and enterobacteriaceae were not detected throughout 15 days of storage. Use of $2 \%$ sesame in the presence of both starter mixtures gave the best sensory scores. Therefore we recommend to use sesame in the production of fermented milk to produce a nutraceutical fermented product rich in omega fatty acids and some other prebiotics e.g.sesamine.
\end{abstract}

Keywords: Nutraceutical fermented milk , Lb. gasseri, Lb. rhamnosus , Sesame seeds, polyunsaturated fatty acids

\section{INTRODUCTION}

Probiotics are defined as selected viable microorganisms used as dietary supplements having potential for improving health of man or animal following ingestion(Gilliland 2001). Some lactobacilli are well known as beneficial bacteria for use as probiotics, and also have a worldwide industrial use as starter cultures in the manufacturing of some fermented milk products. There are a variety of potential health benefits described in the literature resulting from the consumption of products containing live cultures of probiotics. There are specific characteristics that one must consider in developing a product with the goal of delivering health benefits through the consumption of probiotics. Research has shown that among strains within a specific species of lactobacilli significant variation in the ability to provide one or all of the potential health benefits can be seen (Fortina et al. 1998; Janda and Abbott 2002; Buckley and Roberts 2006). Probiotic microorganisms should be at levels of at least $10^{6}$ cfu per gram or milliliter. It was reported that they increase body immunity, outgrow pathogens, improve mineral absorption, reduce blood serum cholesterol, prevent allergy development and inhibit cancer development (Pereira and Gibson 2002; Maiaama and Isolauri 1997; Wollowski et al. ,2001). 
L. gasseri is characterized as an excellent probiotic strain (Fujiwara et al. ;2001), suitable as a starter for marking fermented milk. One of the important beneficial health effects attributed to $L b$. gasseri is its ability to reduce blood serum cholesterol level and protecting from occurrence of mutagenesis of cells caused by food-borne mutagenesis like Trp-P1 (Usman and Hasono, 1999). Also, Atuma and Sato (2001) reported that fermented milk drink prepared with the two novel probiotic lactobaclli (L.gasseri and L.casei ) improved human intestinal microflora. Also L. gasseri improved the properties of the product(shelf-life, flavour and physical properties(Kimura et al. 2003).

Sesame plays an important role in human nutrition. The importance of sesame (Sesamum indicum) as a source of edible oil rich in polyunsaturated fatty acids and high quality protein is continuously increasing. Sesamin is a major lignan constituent of sesame and possesses multiple functions such as antihypertensive, cholesterol lowering, lipid lowering and anti cancer activities. Most of the sesame seeds are used for oil extraction (Elleuch et al. 2007). The chemical composition of sesame shows that it is an important source for oil (50-60\%), protein (18-25\%)and fiber (11.8\%) (Alpaslan et al. 2001, Kahyaoglu and Kaya 2006, Kamel-Eldin and Appelpist, 1994 and Yoshida 1994). Moreover, sesame is exceptionally rich in calcium, iron, magnesium, manganese and, copper and contains vitamin $B 1$ and vitamin $E(\alpha, y, \delta$ tochepherols). Also it contains lignans which are phytoestrogens with antioxidant and anticancer properties. Also contains phytosterols, which reduce levels of blood cholesterol (Cheung et al. 2007).

The present work was undertaken to evaluate the applicability of nutraceutical fermented milk product made by using some lactobacilli and sesame seeds powder as well as following the acceptability of this product throughout 15 days of storage.

\section{MATERIALS AND METHODS}

Fresh raw buffalo's milk was obtained from the Industrial.Dairy Technology Unit, Animal Production Research Institute. Sterptococcus thermophilus was obtained from Chr. Hansen, Copenhagen,Denmark. Lactobacillus gasseri B-14160 (Lb . gasseri) and Lactobacillus rhamnosus B-445 ( $L$. rhamnosus ) were provided from the National Research Center , Egypt.White sesame seeds ( $50 \%$ fat and $20 \%$ protein) were obtained from the local market in Cairo.

Milk was standardized to $3 \%$ fat, then divided into six equal portions. The first portion was heated at $90{ }^{\circ} \mathrm{C}$ for 15 minute, cooled to $37{ }^{\circ} \mathrm{C}$ inoculated with $1.5 \% \mathrm{~S}$. thermophilus and $1.5 \% \mathrm{Lb}$. gasseri. To the second portion sesame seeds powder was added at rate of $2 \%$, heated at $90{ }^{\circ} \mathrm{C}$ for 15 min., cooled to $37^{\circ} \mathrm{C}$ and inoculated as the first treatment. Sesame seed powder was added to the third portion at rate of $4 \%$, heated, cooled and inoculated as the second treatment. The $4^{\text {th }}, 5^{\text {th }}$ and $6^{\text {th }}$ treatments were done as the first 3 treatments but $L b$. rhamnosus was used instead of $L b$. gasseri. The six treatments were poured into polystyrene containers and 
incubated at $37{ }^{\circ} \mathrm{C}$ until coagulation, then kept under refrigeration at $6^{\circ} \mathrm{C}$. Samples were taken from each treatment when fresh and after $3,7,10$,and 15 days for chemical, microbiological as well as organoleptic properties determinations.

\section{Chemical analysis:}

$\mathrm{pH}$ was measured by using a digital $\mathrm{pH}$ meter model Hanna HT4817, Titratable acidity (T.A)according to(AOAC, 2007), Protein content according to ling (1963) and Fat content by Rose Gottlieb method (AOAC, 2007). Free fatty acids were determined in fresh samples and were extracted according to ISO, 14156 (2001), esterified by ISO 15884 (2002)and determined using gas chromatography- GC Hewlett-Packard 6890 by ISO 15885 (2002). Free amino acids were determined by using amino acid analyzer (Eppendorf- LC 3000) according to Block et al (1958).

$L b$. gasseri and $L b$. rhamnosus were counted by plating on MRS agar according to IDF (1995) Str. thermophilus was enumerated on M17 medium. Mould and yeast and enterobacteriaceae counts were determined according to the American Public Health Association (2004).

The sensory evaluation were assessed by members of the Dairy Department, Animal Production Research Institute . Samples were evaluated for flavour (50 points), body and texture (40 points ) and appearance (10 points ) according to Keating and Randwhite (1990).

\section{RESULTS AND DISCUSSION}

Figure (1) show the changes in titratable acidity of the different treatments. It was observed that the T.A increased in all treatments throughout the storage period Furthermore, the addition of sesame increased the T.A. It could be due to the addition of the sesame solids, that affect the total acidity of the product. Moreover the treatments using $L b$. rhamnosus resulted in higher titratable acidity than the other treatments.

Fig (2) indicated the total solids of the fermented milk made from milk fortified with sesame seeds. It was observed that the two control treatments ( $\mathrm{C} 1$ and $\mathrm{C} 2$ ) had the lowest T.S. when fresh and throughout the storage period. While treatments fortified with 2 and $4 \%$ sesame powder had a higher T.S, and the increase in T.S content was parallel to the ratio of sesame added. In all treatments the total solids increased gradually during storage that could be due to evaporation of moisture in the refrigerator.

Protein content of the fermented milk fortified with sesame was shown in fig (3). Addition of sesame increased the protein content and the fat content (data not showed), and it increased by increasing the sesame added. Sesame protein content is in the range of $18-25 \%$ (Murwan et al. 2008). Moreover, treatments manufactured with L. rhamnosus showed a slight increase in protein than the corresponding treatments with $L$. gasseri Furthermore, slight increase in protein content was noticed during 15 days storage.

Table 1 illustrates that the addition of sesame add nutritional value for the product, which is very important for many groups such as the athletes $\mathrm{C} 1$, $1.5 \%$ S. thermophilus $+1.5 \%$ Lb. gasseri (control 1 ), $\mathrm{T} 1,1.5 \% S$. 
thermophilus $+1.5 \%$ Lb. gasseri $+2 \%$ sesame seeds $, \mathrm{T} 2,1.5 \% \mathrm{~S}$. thermophilus $+1.5 \%$ Lb. gasseri $+4 \%$ sesame seeds , C2, $1.5 \% S$. thermophilus $+1.5 \%$ Lb. rhamnousus (control 2) . T3, $1.5 \%$ S. thermophilus+ $1.5 \%$ Lb. rhamnousus $+2 \%$ sesame seeds $, \mathrm{T} 4,1.5 \% \mathrm{~S}$. thermophilus+ $1.5 \%$ Lb. rhamnousus $+4 \%$ sesame seeds

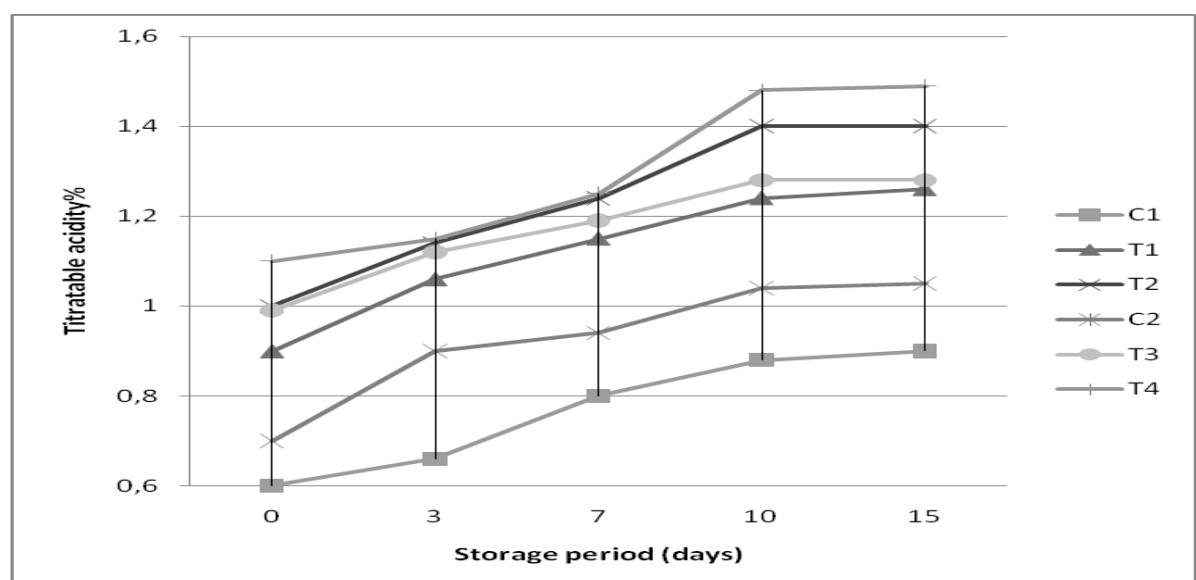

Fig.(1): Changes in titratable acidity of the fermented milk made by using different lactobacilli and sesame during storage at $6^{\circ} \mathrm{C}$.

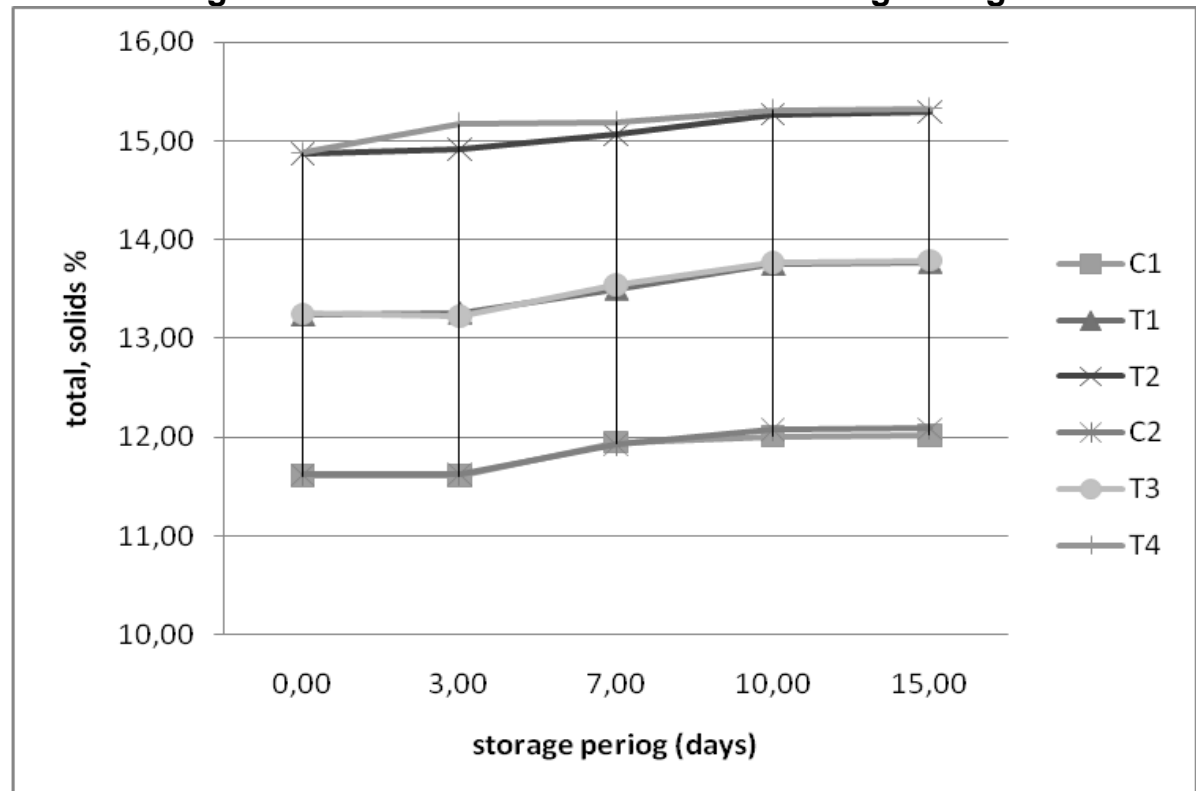

Fig.(2): Changes in total solids of the fermented milk made by using different lactobacilli and sesame during storage at $6^{\circ} \mathrm{C}$.

for abbreviation see Fig. (1) 


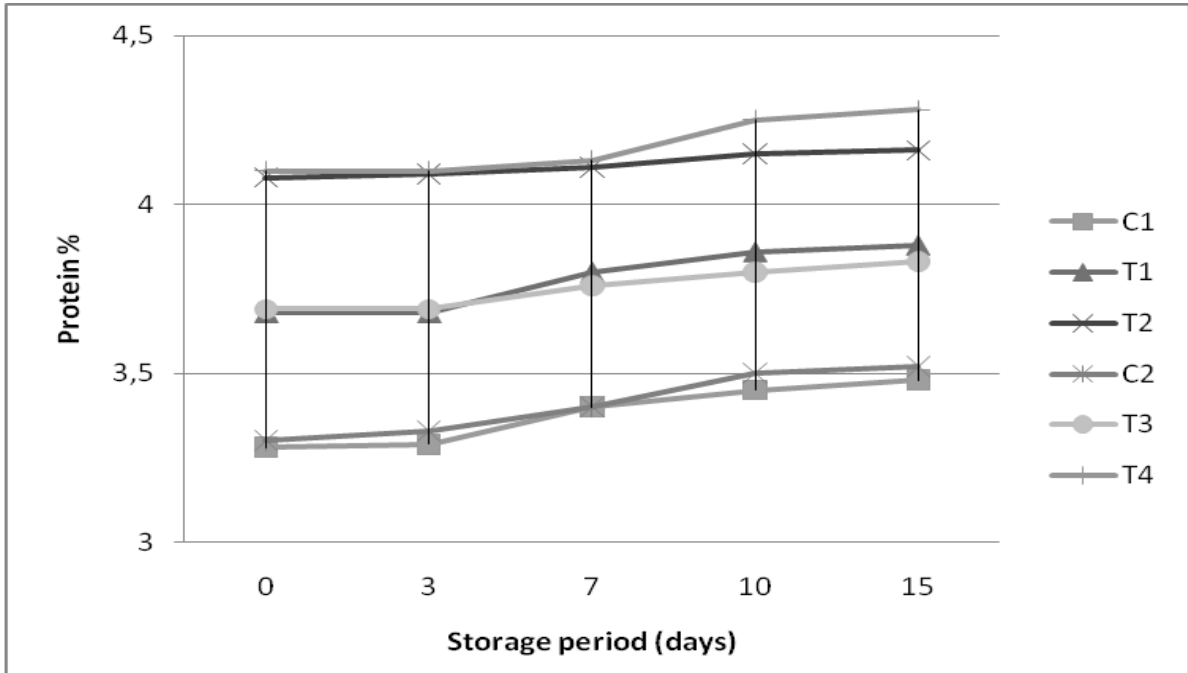

Fig (3): Changes in the protein content of the fermented milk made by using different lactobacilli and sesame during storage at $6^{\circ} \mathrm{C}$. for abbreviation see Fig. (1)

Table (1): The amino acids content of the fresh fermented milk made by using different lactobacilli and sesame. ( $\mathrm{mg} / \mathrm{g}$ protein)+

\begin{tabular}{|l|c|c|c|c|}
\hline Amino acids & C1 & T1 & C2 & T3 \\
\hline Aspartic & 1.72 & 2.51 & 1.77 & 2.9 \\
\hline Threonine * & 0.71 & 1.51 & 0.6 & 1.76 \\
\hline Serine & 1.72 & 2.27 & 1.73 & 2.2 \\
\hline Glutamic & 6.14 & 7.12 & 6.2 & 7.39 \\
\hline Prolin & 1.89 & 2.32 & 1.98 & 2.41 \\
\hline Glycine & 0.4 & 1.17 & 0.46 & 1.15 \\
\hline Alanine & 1.18 & 1.91 & 1.3 & 1.95 \\
\hline Valine * & 1.85 & 2.66 & 1.82 & 2.6 \\
\hline Methionine * & 0.52 & 1.08 & 0.56 & 1.04 \\
\hline Isoleucine * & 0.53 & 1.83 & 0.51 & 1.55 \\
\hline Leucine * & 2.70 & 3.62 & 2.93 & 3.75 \\
\hline Tyrosine & 0.58 & 1.39 & 0.57 & 1.34 \\
\hline Phenylalanine * & 0.56 & 1.73 & 0.52 & 1.68 \\
\hline Histidine * & 1.73 & 2.42 & 1.77 & 2.1 \\
\hline Lysine * & 1.64 & 2.35 & 1.47 & 2.27 \\
\hline Arginine & 1.37 & 2.93 & 1.33 & 2.83 \\
\hline Total essential amino acids & 10.24 & 17.2 & 10.18 & 16.75 \\
\hline Total amino acids & 25.24 & 38.82 & 25.52 & 38.92 \\
\hline
\end{tabular}


Table ( 2 ): The fatty acids content of the fresh fermented milk made by using different lactobacilli and sesame. ( $\mathrm{mg} / \mathrm{g}$ fat)

\begin{tabular}{|l|c|c|c|c|}
\hline Fatty acid contents & C1 & T1 & C2 & T3 \\
\hline \multicolumn{4}{|c|}{ Saturated } & Fatty acids\% \\
\hline Caproic acid & 0.15 & 0.3 & 0.15 & 0.32 \\
\hline Caprylic acid & 0.83 & 0.87 & 0.95 & 1.21 \\
\hline Capric acid & 4.48 & 2.15 & 4.63 & 2.18 \\
\hline Lauric acid & 5.34 & 2.24 & 5.79 & 2.0 \\
\hline Myristic acid & 15.46 & 10.07 & 15.43 & 10.06 \\
\hline Palmitic acid & 36.9 & 30.09 & 36.88 & 30.3 \\
\hline Stearic acid & 8.04 & 8.13 & 8.1 & 8.15 \\
\hline Total saturated & 71.2 & 53.85 & 71.93 & 54.22 \\
\hline & Unsaturated fatty acid \\
\hline Oleic acid & 25.61 & 34.26 & 24.87 & 34.27 \\
\hline Linoleic acid & 2.09 & 10.27 & 2.11 & 9.88 \\
\hline Linolenic acid (omega 6) & 1.1 & 1.62 & 1.09 & 1.63 \\
\hline Total unsaturated & 28.8 & 46 & 28.07 & 45.88 \\
\hline
\end{tabular}

At the same time Table (2), it could be seen that the fatty acids content in fresh fermented milk samples, as they added more value for the products. It was observed that adding sesame increased the total unsaturated fatty acids in T1 and T3 than the corresponding control samples (C1 and C2 ), specially, oleic , linoleic acids and linolenic which are natural antioxidants ( Bahkali, et al.1998; Murwan et al.,2008; Nzikou, et al.2009) ). On the other hand, addition of sesame lowered the total saturated fatty acids in T2 and T3 samples than the controls C1and C2. Furthermore ,palmetic ,myristic and strearic showed the highest ratio between saturated fatty acids. Similar results were obtaind by Nzikou et al (2009), who mentioned that the major saturated fatty acids in sesame seed oil were palmetic and stearic .

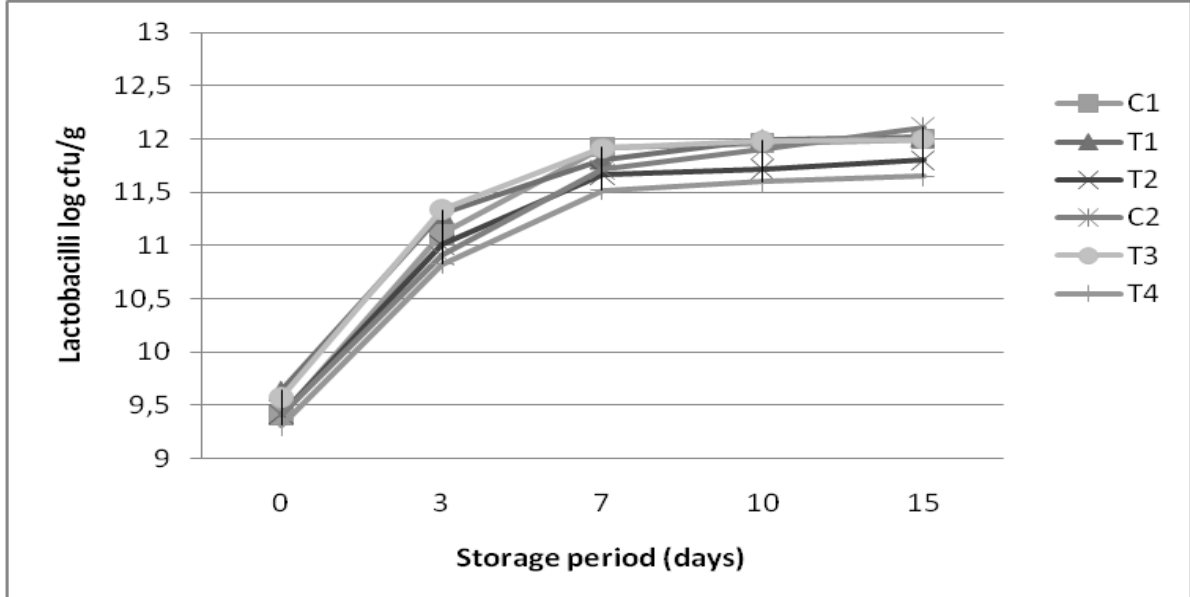

Fig (4): Changes in the lactobacilli counts in fermented milk made by using different lactobacilli and sesame during storage at $6^{\circ} \mathrm{C}$. for abbreviation see Fig. (1) 


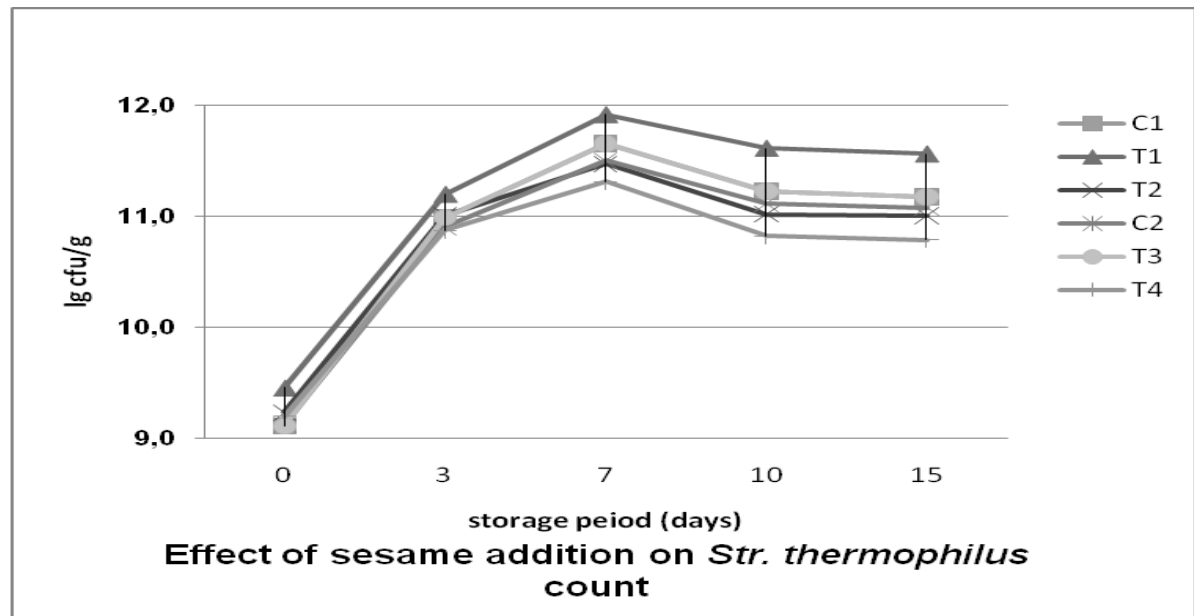

Fig (5): Changes in the Str. thermophilus counts in fermented milk made by using different lactobacilli and sesame during storage at $6^{\circ} \mathrm{C}$.

for abbreviation see Fig. (1)

Fig(4) shows the effect of using sesame in the manufacture of fermented milk on the growth of $L$. gasseri and L. rhamnosus during storage. It was observed that $\mathrm{T} 1$ and $\mathrm{T} 3$ in which sesame were added at ratio $2 \%$ had the highest numbers of both $L$. gasseri and L. rhamnosus when fresh and during the storage period. On the other hand, Lactobacilli count in T2 and T4 were slightly lower than their corresponding controls (C1 and C2). Furthermore, it was clearly noticed that the count of both Lactobacilli strains highly increased after three days for about more than one log cycle and the number also icreased till 15 days but in a lesser rate. Similar results were obtained by Rosenthal et al. (2001), who mentioned that the presence of sesame butter accelerated the growth rate of the starter during fermentation, but did not affect its survival during storage. The growth of Str. thermophilus ( fig 5) also showed the same trend of the lactobacilli, but the number was slightly lower, and after 7 days the count decreased in all treatments. This could be due to the acidity, which affected streptococci more than Lactobacilli (Sharp, 1962). It could also be found that all treatments and the control were free from enterobacteriaceae and yeast and molds when fresh and along the storage period.

Table (3) shows the changes in the organoleptic properties of the fermented milk made with probiotic lactobacilli and sesame .It could be observed that the fermented milk product with $2 \%$ sesame and made with L.gasseri (T1) had the best flavoure during the first 7 days of storage followed by the corresponded product made with $2 \%$ sesame and L. rhamnosus. Also T1 and T3 were of the best body and texture throughout storage. Similar results were obtained by Abdel-Khalek et al (2004) who mentioned that set and stirred yoghurt like products manufactured with Str. thermophilus and $L$. gasseri had the best sensory evaluation. On the other hand, the control 
samples $\mathrm{C} 1$ and $\mathrm{C} 2$ had flat flavour and weak body and texture when fresh due to their low acidity fig. (1). In all treatments the score of body and texture decreased by increasing the storage period and that was clear on T2 and T4 in which wheying off was observed, and the body becomes viscous in T4. These results were in agreement with Rosenahal et al (2001) who observed that sesame butter weakened the clot formed from milk, making it more prone to syneresis.

In conclusion we can recommend the use of sesame and the probiotic lactobacilli $L$. gasseri or $L$. rhamnosus to produce a new fermented dairy product rich in its nutritional value such as antioxidant, fiber, unsaturated fatty acids, minerals ...etc. and acceptable for the consumer.

Table (3): Sensory evaluation of the fermented milks made with probiotic lactobacilli and fortified with sesame.

\begin{tabular}{|c|c|c|c|c|c|}
\hline Treatments & $\begin{array}{l}\text { storage } \\
\text { period(days) }\end{array}$ & $\begin{array}{c}\text { Flavour } \\
50\end{array}$ & $\begin{array}{c}\text { Body and } \\
\text { Texture } \\
35\end{array}$ & $\begin{array}{c}\text { Appearance } \\
15\end{array}$ & $\begin{array}{c}\text { Total } \\
\text { scores } \\
100\end{array}$ \\
\hline \multirow[t]{5}{*}{ C1* } & fresh & 42 & 31 & 12 & 85 \\
\hline & 3 & 42 & 31 & 12 & 85 \\
\hline & 7 & 43 & 31 & 12 & 86 \\
\hline & 10 & 41 & 31 & 12 & 84 \\
\hline & 15 & 37 & 29 & 12 & 78 \\
\hline \multirow[t]{5}{*}{$\overline{T 1}$} & fresh & 45 & 33 & 12 & 90 \\
\hline & 3 & 45 & 32 & 12 & 90 \\
\hline & 7 & 45 & 32 & 12 & 89 \\
\hline & 10 & 41 & 30 & 12 & 83 \\
\hline & 15 & 40 & 28 & 11 & 79 \\
\hline \multirow[t]{5}{*}{ T2 } & fresh & 42 & 33 & 12 & 86 \\
\hline & 3 & 42 & 32 & 12 & 86 \\
\hline & 7 & 41 & 31 & 12 & 84 \\
\hline & 10 & 39 & 30 & 11 & 80 \\
\hline & 15 & 33 & 27 & 10 & 70 \\
\hline \multirow[t]{5}{*}{ C2 } & fresh & 41 & 30 & 12 & 83 \\
\hline & 3 & 42 & 30 & 12 & 84 \\
\hline & 7 & 41 & 31 & 12 & 84 \\
\hline & 10 & 41 & 31 & 12 & 84 \\
\hline & 15 & 35 & 30 & 12 & 77 \\
\hline \multirow[t]{5}{*}{ T3 } & fresh & 43 & 32 & 12 & 87 \\
\hline & 3 & 43 & 32 & 12 & 87 \\
\hline & 7 & 40 & 31 & 12 & 83 \\
\hline & 10 & 39 & 30 & 12 & 81 \\
\hline & 15 & 38 & 29 & 12 & 79 \\
\hline \multirow[t]{5}{*}{ T4 } & fresh & 41 & 32 & 12 & 85 \\
\hline & 3 & 41 & 31 & 12 & 84 \\
\hline & 7 & 41 & 30 & 12 & 83 \\
\hline & 10 & 38 & 29 & 11 & 78 \\
\hline & 15 & 33 & 24 & 10 & 67 \\
\hline
\end{tabular}

* for abbreviation see Fig. (1) 


\section{REFERENCES}

Abou-Garbia, H.A., A.A.Y. Shehata and F.F.Shahidi, (2000). Effect of processing on oxidative stability and lipid classes of sesame oil. Food Res. Intl., 33:331-340.

Abdel- Khalek A.B.,B.A. Effat and O.M. Sharaf,(2004). The use of Lactobacillus gasseri, lactopacillus johnsonii and genetically modified Lactopacillus delbreuckii ssp. bulgaricus in functional yoghurts- like products. Egyption J. Dairy Sci. 32: 245-259.

Alpaslan, M., Boydak and M. Demircim, 2001. Protein and oil composition of soybean and sesame seed grown in the Harran (GAP) area of Turkey. Session 88B, Food Chemistry: Food Composition and Analysis.

American Public Health Association (2004). Standard Method for the Examination of Dairy Products .18th Ed. Washington ,USA .

AOAC " Association of Official Analytical Chemists" (2007) Official Methods of Analysis 17th Edition. Association of Analytical Chemists INC., suite 400,2200 Wilson Boulevard, Arlinton, Virginia 22201, USA.

Atuma, Y. and Sato, M. (2001). Lactobacillus casei NY1301 increases the adhesion of Lactobacillus gasseri NY0509 to human intestinal Caco 2 cells. Biosci. Biochem .65:2326.

Bahkali, A.H. M. ; A. Hussain and A.Y. Basahy, (1998) Protein and oil composition of sesame seeds (Sesamum indicum, L.) grown in the Gizan area of Saudi Arabia. International J. Food Science and Nutrition 49, 409-414.

Block,R.J.; E.L.Durrum, and B. Zweig (1958). Manual of paper chromatography and paper electrophoresis. 2nd Ed. Academic Press.INC. Publishers, New York.

Buckley, M.,Roberts,R.J.(2006) Reconciling Microbial Systematics \& Genomics. Washington DC;American Academy of Microbiology. $11 \mathrm{p}$.

Cheung SC. ,YT Szeto and IF.Benzie (2007) Antioxidant protection of edible oils. Plant Foods Hum Nutr.62(1): 39-42.

De Vuyst,L.(2000). Technology aspects related to the application of functional starter cultures. Food Technol. Biotechnol. 38:105.

Elleuch,M., S. Besbes, O. Roiseux, C. Blecker and H. Attia, (2007) Quality characteristics of sesame seeds and by- products. Food Chemistry, 103: 641-650.

Fortina, M.G., Nicastro, G, Carminati, D., Neviani, E, Manachini, PL.(1998). Lactobacillus helveticus heterogeneity in natural cheese starters : the diversity in phenotypic characteristics. J.Appl.Microbiol.84 (1):72-80

Fujiwara, S.; Seto, Y.; Kimura, A. and Hashibia,H.(2001). Establishment of orally-adminstered Lacatobacillus gasseri SBT2055SR in the gastrointestinal tract of humans and its influence on intestinal microflora and metabolism. J. Appl. Microbiol.90:3430. 
Gilliland SE (2001) Technological and commercial applications of Lactic acid bacteria : Health and nutritional benefits in dairy products. Presented at the joint FOA/WHO Expert Consultation on Evaluation of Health and Nutritional Properties of Probiotics in Food Including Powder Milk with Live Lactic Acid Bacteria. Cordoba, Argentina, October 1-4. International Dairy Federation (1995).Detection and enumeration of lactopacillus acidphilus . Bulletin No. 306. o

ISO 14156 .Milk and products extraction methods for lipids and lipo soluble compounds. International Organization for Standardization 2001, E.

ISO 15884.Milk fat preparation of fatty acid methyl ester. International Organization for Standardization 2002, E.

ISO 15885. Milk fat determination of fatty acid composition by gas-liquid chromatography. International Organization for Standardization 2002, E.

Janda,J.M., Abbott,S.T.(2002) Bacterial Identification for Publication : When Is Enough Enough? J.Clin.Microbiolo.40(6): 1887-1891.

Kahyaoglu, T. and S. Kaya, (2006). Modelling of moisture, color and texture changes in sesame seeds during the conventional roasting. J. Food Eng., 75: 167-177.

Kamel- Eldin, A. and L.A. Appelpvist, (1994). Variation in fatty acid composition of the different acyl lipids in seed oils of four Sesamum species. J. Am. Oil Chem. Soc., 71: 135-139.

Keating,K. and Randwhite,S. (1990) Effect of alternative sweeteners in plain and fruit flavoured yoghurt. J. Dairy Sci. 37-54

Kimura ,K ; Koga ,H . and Yaseuhiro , I . (2003).Strain of Lactobacillus gasseri . U.S. Patent No . 6,596,530.

Ling, E.R. (1963) Text Book of Dairy Chemistry vol. 11. Practical champan and hall L.T.D. London 3 rd ed. pp. 140.

Maiaama, M., and E. Isolauri. (1997). Probiotics: a noval approach in the magement of food allergy.J. Allergy Clin. Immune.99,179-185

Murwan K. Sabah E. , K .E. A. Ishag and A. A. Yagoub .(2008) Chemical Composition and Oil Characteristics of Sesame Seed Cultivars Grown in Sudan. Research J. Agriculture and Biological Sciences, 4(6): 761766.

Nzikou J.M., L. Matos, G.Bouanga- Kalou, C.B. Ndangui,N.P.G. PambouTobi, A.Kimbonguila, Th. Silou, M. Linder and S. Desobry,(2009). Chemical composition of the seeds and oil of sesame (Sesamum indicum L.) grown in Congo-Brazzaville. Advance J. Food Science Technology 1(1):6-11.

Pereira, D.I., and G.R. Gibson(2002) Cholesterol assimilation by lactic acid bacteria and Bifidobacteria isolated from the human gut.. Appl. Environ. Miicrobiol. 68,4689.

Rosenthal, I; Berstein, S and Huberman, L(2001) Evaluation of mixtures of milk and sesame butter fermented with yogurt culture. Milchwisserschaft.2001; 50(4):210-212

Sharp, E .M. (1962). Taxonomy of the lactobacilli: Dairy. Sci. Abst. Rev. 24 109-16. 
Usman, A. and A. Hosono, (1990).Viability of Lactobacillus gasseri and its cholesterol -binding and antimutagenic activities during subsequent refrigerated storage in nonfermented milk . J. Dairy Sci. 82:2536 .

Wollowski,I., G. Rechkemmer and B.L. Pooi-Zobel(2001). Protective role of probiotics and prebiotics in colon cancer. Am. J. Clin. Nutr. 73(suppl.2), 451s-455s.

Yoshida,H., (1994). composition and quality characteristics of sesame seed(Sesamum indicum) oil roasted at different temperatures in an electric oven. J.Sci. Food Agricul., 65:331-336.

استخدام السمسـم وبعض المـدعمات الحيويـة من بكتريـا حمض النلاكتيك العصدية

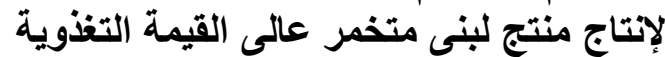

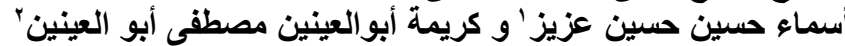
ا-قسم تكنولوجيا الألبان ، ؟ ـ قسم كيمياء بحوث الألبان - معهد الإتتاج الحيوانى العين

فى هذا البحث تم استخدام السمسم كمصدر غنى بالأحماض الدهنية طويلـة السلسلة عديدة

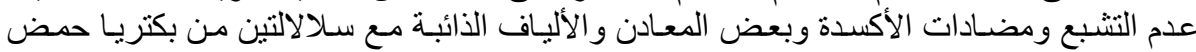

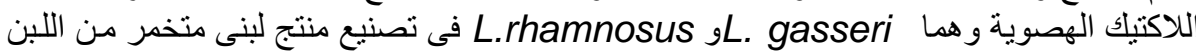
الجاموسى المعدل تركيبه وكانت المعاملات كالاتى:مقارنة 1.5\% + 1.5\% S. thermophilus 1.5\% S. thermophilus+ 1.5\% Lb. ، r r r. 1.5\% Lb. gasseri

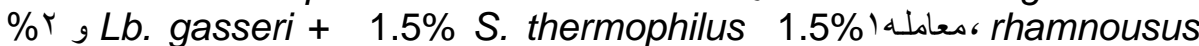

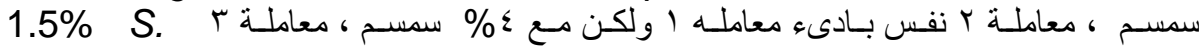
thermophilus+ 1.5\% Lb. rhamnousus

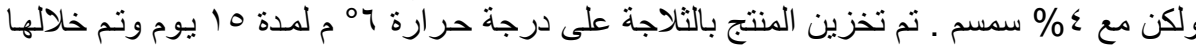

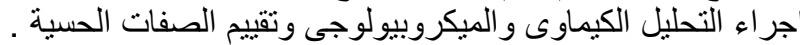

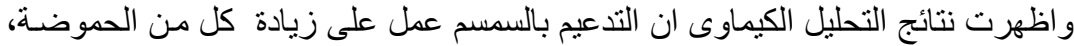

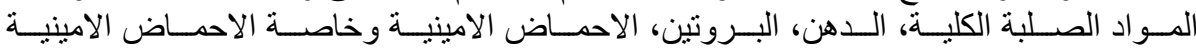

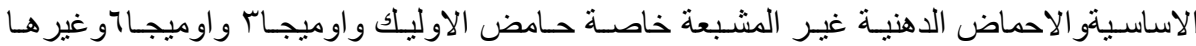

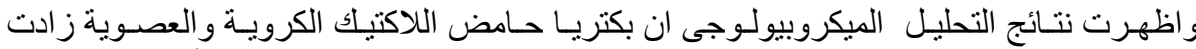

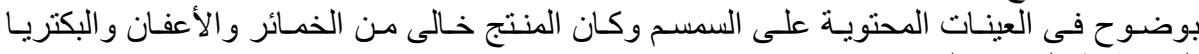
المعوية طو ال فترة التخزين التونين

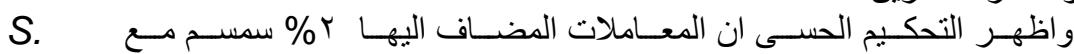
Lb. gasseri gthermophilus

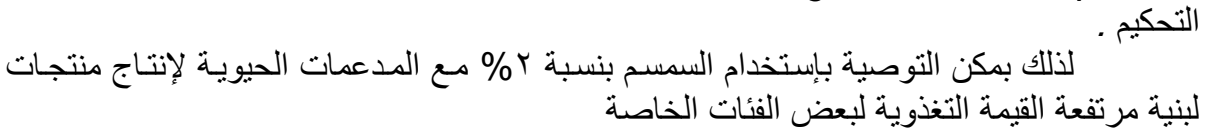

كلية الزراعة - جامعة المنصورة

قام بتحكيم البحث كلية الزراعة - مامعة القاهرة

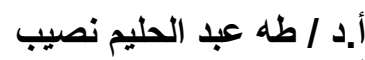

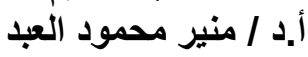

